\title{
Representing the National Economic Agenda in Latin America: Variation by Fat and Lean Times and Party Brands
}

\author{
Oscar Castorena
}

and

Elizabeth J. Zechmeister*

\begin{abstract}
Representation is greater when legislators and voters agree on the national agenda. Under what conditions are higher degrees of "issue priority representation" more likely? Our answer focuses on economic conditions and party branding dynamics, and the case of Latin America. With mass and elite survey data we show that economic hard times and left-leaning preferences increase the prioritization of economic issues. In accord with that finding, we document fairly high levels of economic issue priority representation in most of Latin America. From the perspective of democratic quality, evidence of representation in this domain is good news; yet, variation does exist. Consistent with our argument that party branding dynamics matter, we find that leftist and centrist parties tend to over-prioritize economic issues relative to their supporters, and the reverse for rightist parties. Further, we find a significant interaction between economic conditions and the ideological brand of parties: in economic downturns the left and the center are more likely to express a strong commitment to economic performance, whereas the right is less responsive to lean times.
\end{abstract}

Key words: Representation, Issue Priorities, Economy, Party Brands, Latin America

Previous versions of this paper were presented at workshops at the University of Maryland, College Park, MD, May 2015 and Texas A\&M University, College Station, TX, March 2016. We thank the workshop organizers and participants for feedback on the project. This material is on work supported by a National Science Foundation Graduate Research Fellowship (NSF \#). 


\title{
Representing the National Economic Agenda in Latin America: Variation by Fat and Lean Times and Party Brands
}

\begin{abstract}
Representation is greater when legislators and voters agree on the national agenda. Under what conditions are higher degrees of "issue priority representation" more likely? Our answer focuses on economic conditions and party branding dynamics, and the case of Latin America. With mass and elite survey data we show that economic hard times and left-leaning preferences increase the prioritization of economic issues. In accord with that finding, we document fairly high levels of economic issue priority representation in most of Latin America. From the perspective of democratic quality, evidence of representation in this domain is good news; yet, variation does exist. Consistent with our argument that party branding dynamics matter, we find that leftist and centrist parties tend to over-prioritize economic issues relative to their supporters, and the reverse for rightist parties. Further, we find a significant interaction between economic conditions and the ideological brand of parties: in economic downturns the left and the center are more likely to express a strong commitment to economic performance, whereas the right is less responsive to lean times.
\end{abstract}


Keywords: Representation, Issue Priorities, Economy, Party Brands, Latin America Political representation is greater when elected representatives and voters agree on the national agenda. In theory, electoral competition should create congruence between political elites and the mass public with respect to which issues take priority. Politicians and parties select performance goals to emphasize in campaigns and the public sends politicians to office with mandates to achieve particular outcomes, such as increasing economic growth or bolstering security (see Hart 2013; Londregan 2000; Stokes 1963; Vavreck 2009). Elected representatives also ought to be sensitive to the same contextual shifts that change national priorities among the mass public, because electoral mechanisms incentivize responsiveness. Yet, congruence between legislators and their supporters on issue priorities is not a given, in particular in parts of the world where meeting the ideals of programmatic party competition has proven particularly challenging, such as is the case in Latin America (Kitschelt et al. 2010). Unpacking the dynamics and nature of issue priority representation in provides important insight into this often overlooked facet of political representation and, as well, into the quality of democratic representation in Latin America.

We focus on the place of the economy within the national agenda, and ask three questions. ${ }^{1}$ First, what factors lead the mass public and parliamentary elites to prioritize the economy over other issues when determining the national agenda? Second, to what extent is there evidence of economic issue priority representation (that is, congruence in priorities)? Third, what factors predict correspondence between legislative elites and the public on economic issue prioritization?

In addressing these questions, we consider two theoretical influences on issue priorities and representation -- actual conditions (fat and lean times) and party branding dynamics --, and we introduce the notion that these factors interact in ways that can tamp down on issue priority representation. On the one hand, one might suspect that congruence over a particular issue is higher when problems in that domain sharpen attention on it (see Singer 2010). That is, when

\footnotetext{
${ }^{1}$ A focus on the economy fits the theme of this symposium and is justified by the fact that it is typically the most salient issue in elections in the region (see Baker and Green 2015; Carlin, Singer, and Zechmeister 2015; Gélineau and Singer 2015; Kitschelt et al. 2010).
} 
economic output is poor or declining, the public and elites ought to coalesce in the prioritization of this issue. Yet, on the other hand, party branding dynamics stemming from "issue ownership", also matter. In brief, we argue that the tendency for parties to systematically and strategically stake out reputations on issues according to their ideological party family (e.g., Budge and Farlie 1983; Petrocik 1996) leaves an imprint on voter and legislator issue priorities that can diminish the correspondence among them, relative to what is ideal.

We develop empirical assessments of issue priorities and issue priority representation with mass public and legislative elite survey data from the AmericasBarometer by LAPOP and the Parliamentary Elites of Latin America (PELA) project by the University of Salamanca. To measure issue priorities, we use "most important problem" questions. We assess the predictors of economic issue prioritization at both the elites and mass levels, focusing on economic factors and ideological brands. We continue on to examine the extent of correspondence in issue priorities across the mass public and elected representatives. Here we pay particular attention to variation, across economic conditions (fat and lean times) and ideologically-distinct party families (brands), in the degree of correspondence between supporters and legislators on economic issue prioritization.

Our core findings are as follows: First, in economic hard times, the public and legislative representatives place greater weight on economic issues, while conversely such economic priorities are more relaxed during economic good times. Further, dynamics consistent with ideological party branding are present among citizens and politicians alike: those to the left are more likely to report concern for economic issues, relative to those on the right. This result is consistent with the notion that parties position themselves to build brand identities: legislators situated outside the ideological right are incentivized - by their supporters' preferences and their own goals of building out issue ownership - to stake out a comparatively stronger valence position on economic issue prioritization. Second, levels of economic issue priority representation are fairly high in most Latin American countries. This is important because it has implications for the quality of democratic politics in the region. Extant scholarship tends to find that, despite evidence of policy-based voting in some countries under some conditions (Baker and Greene 2015; Zechmeister 2008), elite-mass congruence on specific policy stances is weak 
on average and uneven across countries (Dow 1998; Luna and Zechmeister 2005; Stokes 1999), though representation based on more general ideological schema may be higher (Saiegh 2015). Issue priority representation is not a rival or substitute for policy-based representation; rather, the presence of issue priority representation provides evidence of a more robust set of linkages between the public and their elected officials than one would find by looking at policy-based representation alone.

Third, when we examine correlates of economic issue priority representation, we again find evidence of party branding dynamics: the ideological family of the party matters, such that leftist and centrist parties signal ownership of economic issues by over-prioritizing them relative to their supporters, and the reverse for right wing parties. Fourth, returning once again to the core theme of this symposium, we find a significant interaction between economic conditions and the ideological profile of the party in predicting correspondence on economic issue priorities: in economic down times the left and the center are more likely to signal investment in prioritizing economic issues, whereas the right is less responsive to economic downturn.

\section{Mandates, Issues, and Representation}

In common parlance, politicians are elected with mandates from the public. Mandate representation is achieved when representatives act and deliver outcomes in the "best interest" of the mass public (see Federalist 10; Pitkin 1967; Manin, Przeworski, and Stokes 1999). Among political scientists, a long-standing tendency has been to focus on policy-based mandate representation - that is, the degree to which party supporters and party elites (e.g., legislators) correspond in their position-taking on either a general ideological dimension or specific policy dimensions. Yet, while positional representation and the policy-based voting required to undergird it may be theoretically alluring because of their connection to responsible party government (Adams 2001) and programmatic party structuration (Kitschelt et al. 2010), this type of representation is only one among many. ${ }^{2}$ To extend beyond that one perspective, we focus on issue priority representation for two core reasons. First, a shared national agenda over

\footnotetext{
2 Another type, which is non-rival to the focus of this paper is at the center of the "accountability representation" model. From this perspective, representation is achieved when voters monitor the performance of elected officials and retrospectively sanction or censure them at the polls (Manin, Przeworski, and Stokes 1999).
} 
performance goals is relevant to accountability and representation dynamics in democratic representative politics. As Jones and Baumgartner (2004) state, "problem solving is a critical component of competent government (p. 1)." Theoretically, in a representative democracy, the national agenda expressed by agents (legislative representatives) ought to mirror the agenda prioritized by the voting public. ${ }^{3}$

Second, it is frequently the case that voters are oriented toward issue priorities ${ }^{4}$ and that politicians campaign on issue priorities (see Stokes 1963; Vavreck 20095), and this may be particularly the case in more fluid presidential party systems, which are characteristic of the Latin American region. In a study of the Latin American voter, Carlin, Singer, and Zechmeister (2015) conclude that the period after a transition from authoritarianism (or one party dominance) to competitive party politics is not one that quickly results in a stable equilibrium outcome. Rather, "the menu of political actors and parties ebbs and flows along with the content of the platforms they advocate and represent. To the extent Latin America is exemplary of posttransition politics in general, this political fluidity can last for decades." And, in fact, it may be common for systems to become even more fragmented during this time period and to endure a steady stream of inter-institutional crises (Mainwaring and Zoco 2007; Helmke Forthcoming), a development that has been linked to increased difficulty by the public to navigate the political system using ideological markers (Zechmeister and Corral 2013; Carlin, Singer, and Zechmeister 2015). ${ }^{6}$ In short, in contexts such as Latin America, muddled and shifting political arenas can make policy- and ideological-based voting more difficult; in these contexts in particular,

\footnotetext{
${ }^{3}$ Admittedly, this sets a lower bar for the quality of the democratic process (see discussion in Powell 2004). Yet, it is a bar that - when met - signals at least some degree of responsiveness by elected officials to citizen demands.

${ }^{4}$ Constraints at the individual level fuel the relevance of issue priorities in electoral politics. As "rationally ignorant" individuals, most citizens have little sense of their own policy stances let alone those of politicians and parties (Downs 1957; Campbell et al. 1960; Converse 1964).

${ }^{5}$ Of course, campaigns very in the extent to which they emphasize issues, cleavages, or other factors; for a detailed analysis of variation across countries in Latin American campaigns, see Boas (2016).

6 Parties and party systems in the recently transitioned region splinter easily under exogenous shocks such as economic decline and recover only very slowly (Kitschelt et al. 2010; Morgan 2011; Lupu 2016).
} 
politicians and the public may find it relatively easier to send and receive signals on issue prioritization. ${ }^{7}$

In fact, in Latin American contexts in which voters face numerous choices at the polls, the public has an inclination toward selecting politicians based on the single most important issue (see, e.g., Cunow 2014) and to prioritize performance (Gélineau and Singer 2015; Carlin, Singer, Zechmeister 2015). This, in turn, theoretically motivates an orientation among politicians toward issue priorities (see Hart 2013). ${ }^{8}$ That said, a focus on issue goals and performance is not unique to Latin American electoral politics (see Achen and Bartels 2016; Fiorina 1981; Lewis-Beck and Paldam 2000); rather, a general tendency for parties to compete "by stressing the priority of certain topics" is found across many party systems (Budge 1993; Budge and Farlie 1983). ${ }^{9}$

In summary, for various reasons, issue priority representation is an appropriate derivation of mandate representation to examine and assess, in general and in particular in the Latin American context. To better understand the nature of economic issue representation, we need to answer at least three questions. What are the underpinnings of economic issue prioritization, and are they the same across the mass public and elected officials? How much congruence is there across the mass public and elites in economic issue prioritization? And, finally, what factors lead to divergence in parties' tendencies to reflect their supporters' economic issue priorities? The next section addresses the first of these questions.

\section{Economic Issue Prioritization}

\footnotetext{
7 When choices are less clear, individuals are less likely to make decisions based on policy stances (Abramson, Aldrich, and Rohde 1999; Alvarez and Nagler 2004; Dow 1998; Page and Brody 1972; Page 1978; Zechmeister 2008).

8 This orientation also makes plausible the argument that the recent wave of leftism that swept across Latin American in the form of a "pink tide" was driven more by frustration with economic performance of right-leaning incumbent parties than a mass ideological conversion (Murillo, Oliveros, and Vaishnav 2010; Queirolo 2013; but see Baker and Greene 2011). We return to this briefly in the conclusion. The orientation also likely underlies the tendency for voters to forgive extreme policy switches when performance improves (Stokes 1999).

${ }^{9}$ A long line of scholarship supports the notion that it is generally difficult for politicians to clearly convey their issue positions (and often they lack motivation to do so), while easier for individuals to identify performance goals and outcomes (see footnote 5; also, Fiorina 1981; Shepsle 1972). With respect to presidential systems in particular, Samuels and Shugart $(2003,2006)$ argue that these tend to be especially inhospitable to representation based on policy platforms because separation of powers and other features of a presidential system distance the president from the party, which reduces the executive's incentives to toe consistently the party line.
} 
What leads members of the mass public and political elites to place issues related to the economy at the top of the issue agenda? We consider the influence of economic conditions and party branding dynamics. In the first place, we expect that both citizens and elites will be more likely to prioritize the economy when output is poor. Singer (2010) has demonstrated that the public gives more weight to the economy during poor fiscal times, and we expand on this by asking whether the public takes into consideration both egotropic and sociotropic factors in the decision to identify the economy as the most important problem facing the country. We further examine whether legislators likewise respond to downturns by giving greater priority to the economy, and conversely less attention to this issue area during economic good times. In the second place, we ask whether ideological positioning matters. Our consideration of this factor is grounded in the expectation that issue branding dynamics will shape issue prioritization. Specifically, we expect that both individuals and parties that are in families located on the ideological left will be more likely to prioritize the economy, a symmetrical relationship we associate with what we see as an incentive for leftist parties to establish a reputation for being more committed to, and by proxy more capable of, managing the economy.

\section{The Mass Public and Economic Issue Prioritization}

In recent times, the Latin American public's prioritization of economic issues declined in step with the economic growth that the region witnessed, on average, over the past decade. Data from the AmericasBarometer surveys by $\mathrm{LAPOP}^{10}$ provide a portrait of issue prioritization by the mass public through responses to a question that asks individuals, "In your opinion, what is the most serious problem faced by the country?" The open-ended question is coded in the field by interviewers into between thirty-five and forty pre-established categories. We processed those codes into five categories: a) the economy; b) security; c) governance; d) infrastructure; and e)

\footnotetext{
10 The AmericasBarometer datasets for Latin America are based on national samples and in-person interviews at respondents' households. We thank LAPOP and its supporters for making the data available. All data, codebooks, and technical information for the surveys are available at www.vanderbilt.edu/lapop.
} 
other. ${ }^{11}$ It is important to note that the question does not ask about which issue should be prioritized, but rather which problem is most important; we consider this a reasonable measure of the problem that citizens rank as most pressing and, by extension, most in need of attention by those capable of offering solutions. As Wlezien (2005) indicates, given that most important problem questions do not explicitly ask respondents to identify the most important issue, our measure of issue priorities is more accurately a measure of problem priorities.

Figure 1 presents these data for each wave of the AmericasBarometer as they average out across the 18 countries that constitute the Latin American region. ${ }^{12}$ Two issue areas dominate the concerns of the mass public in contemporary Latin America: economic and security. Further, since 2004 economic issues have declined in salience relative to security and infrastructure issues. These results are consistent with the notion that during times of economic boom, the mass public's attention turns away from the economy and toward the prioritization of other issue areas (and vice versa, per Singer 2010). ${ }^{13}$

\title{
Figure 1. Distribution of Most Important Problem Issue Areas over Time, Latin America
}

\begin{abstract}
11 If the respondent identified economic problems in general, inflation, poverty, unemployment, income/land inequality, foreign debt, market or free trade issues, then the respondent was coded as prioritizing the Economy. On the other hand, if the respondent indicated public insecurity, crime, violence, narco-trafficking, armed conflict, gangs, terrorism, kidnapping, forced displacement, or security in general as the most important problem, then the respondent was coded as prioritizing Security. Corruption, politicians, and related responses were coded as Governance. Housing, education, streets and related issues were coded as Infrastructure. Another reasonable label for this basket would be Services, which like security and governance programs can have economic implications but do not specifically reference economic performance as a general topic.
\end{abstract}

12 The countries we include as Latin America are Mexico, Guatemala, El Salvador, Honduras, Nicaragua, Costa Rica, Panama, Colombia, Ecuador, Bolivia, Peru, Paraguay, Chile, Uruguay, Brazil, Venezuela, Argentina, and the Dominican Republic. The results in the figure naturally mask cross-national differences and, instead, display an average for the region. We consider countries to be units of analysis and therefore weight each country the same in this presentation of results for the region. All analyses in this paper are conducted using Stata and the necessary weights to account for the complex sample design. The first wave of the AmericasBarometer (2004) included 11 countries; if we restrict the analysis to those countries only, the general patterns remain the same.

${ }^{13}$ We find a similar pattern for Latin American legislators; when we regress the percentage of legislators identifying the economy as the most important problem on time, we find a negative, statistically significant relationship (results available upon request). In the next sub-section we document the influence of economic conditions on elite responses to the most important problem question. 


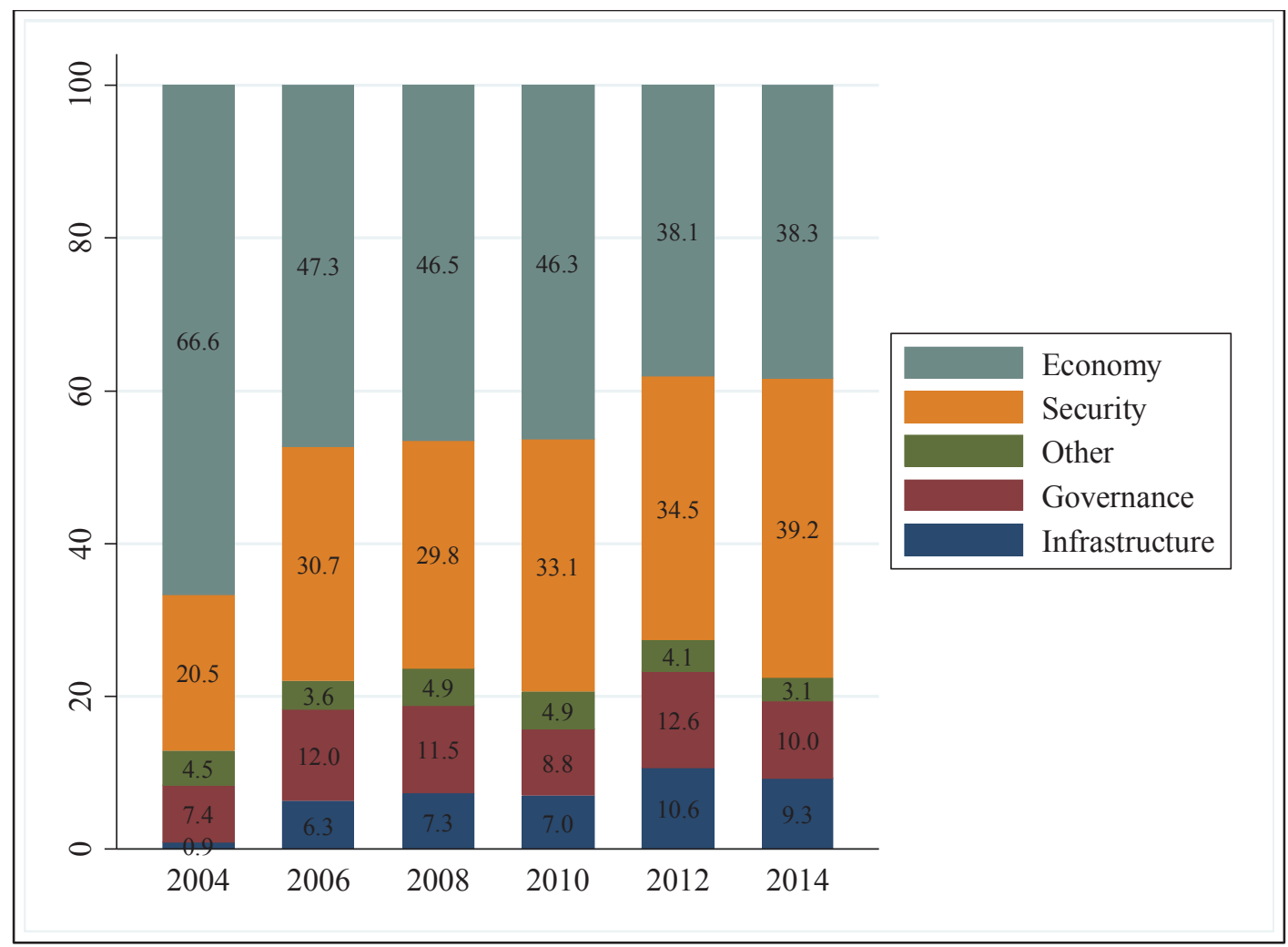

What other factors influence the tendency to emphasize or de-emphasize the economy as an issue for the national agenda? One possibility is that personal economic situations matter alongside national output. The notion that citizens might take into account egotropic considerations has a well-known analogue in scholarship on retrospective economic voting, where scholars have debated for decades over the extent to which individuals take into consideration their own economic circumstances when making decisions over candidates and evaluating executive approval (Kinder and Kiewiet 1979, 1981; Lewis-Beck 1988). The dominant argument is that individuals tend to view their personal economic situations as less the responsibility of national government and, therefore, do not give much weight to their household finances in their voting decisions (Kinder and Kiewiet 1981, 132). In a parallel manner, one might expect that individuals will not be more motivated to place the economy on the national agenda simply because their own personal financial situations are in duress. Yet, in assessing factors that predict the prioritization of security as an issue in the Latin American region, [citation omitted] find that individual experiences with crime victimization have a positive significant effect, albeit small in 
size. Therefore, there is at least some empirical reason to suspect that individuals in the region do tend, on average and all else equal, to be more to give national-level priority to issues on which they are experiencing personal difficulties.

Another set of factors that could influence economic issue prioritization relates to the ideological leanings of individuals. While spatial ideological positioning is typically related to policy-based voting models, the issue competency and ownership frameworks developed by Budge and Farlie (1983) and Petrocik (1996) support an expectation that such positioning influences issue prioritization. In short, these scholars (Budge 1993; Budge and Farlie 1983; Petrocik 1996; Petrocik, Benoit, and Hansen 2003) highlight the fact that parties attain reputations for competence in particular issue areas and reinforce these by emphasizing those issue areas in campaigns. ${ }^{14}$ Generally speaking in Latin America, right-leaning parties tend to be associated with security issues, while the left is understood to occupy itself relatively more with economic statist and welfare issues (Levitsky and Roberts 2011). Clearly right parties also advocate for economic issues, but in the Latin American region rightist economic programs aimed at reducing state intervention in the economy and provision of welfare (e.g., poverty relief) have been so unpopular that executives seeking to enact them have at times campaigned under the guise of pro-state, pro-welfare leftist platforms followed by surprise "policy switches" that reverse course after the election (Stokes 1999). Assuming these brands are fueled by and translate into sorting patterns among the mass public, we expect those with left-leaning tendencies to give greater priority to economic issues.

To assess these expectations at the level of the mass public, we make use of the 2010, 2012, and 2014 rounds of the AmericasBarometer for the 18 Latin American countries. ${ }^{15}$ Our dependent variable is a measure of economic issue prioritization based on individuals' responses to the "most serious problem" question. As noted previously, the open-ended question is coded in the field into pre-established categories and, if those categories relate to economic problems in

\footnotetext{
14 Party branding dynamics thus become another factor fueling the salience of issue priorities in campaigns, as candidates are incentivized to compete by framing "the vote choice as a decision to be made in terms of problems facing the country that he is better able to handle than his opponent (Petrocik, 1996, 826)." See also Neundorf and Adams (2016) on the tendency for voters' issue priorities in Western Europe to be influenced by parties and partisanship.

${ }^{15}$ We focus on the 2010-2014 rounds because these contain the policy questions that we use in the model.
} 
general, inflation, poverty, unemployment, income/land inequality, foreign debt, market or free trade issues, then the respondent was coded as prioritizing the Economy.

Our indicator of personal economic decline is a question that asks whether an individual experienced income loss in his or her household over the prior two years. We measure national economic conditions in two ways: first, the proportion of individuals in the country for that survey year who say that they experienced income loss and, second, the percent change in GDP per capita for the year leading to the survey year for each country. ${ }^{16}$ We measure economic ideology with two questions about the role of the state, one with respect to the ownership of major industries (versus privatization) and the other about whether the state (versus private actors) should take key responsibility for reducing inequalities. ${ }^{17}$ We avoid using left-right selfplacement as an indicator of economic ideology at the level of the mass public, given evidence that economic policy stances are weakly or not predictive of left-right self-identifications among the Latin American public (Zechmeister 2015). We control for individual crime victimization, given the above-noted finding that this positively affects individuals' tendencies to prioritize a rival issue, security (citation omitted). At the level of the individual we further control for a set of basic socio-economic and demographic factors: urban (versus rural) residence, female gender, age, skin tone, education, and wealth. ${ }^{18}$ At the level of the country we include a measure of the proportion of adults victimized by crime in the year of the survey and country fixed effects (the latter included to control for the fact that each country is represented two to three times in the dataset; these are not shown in the table for sake of parsimony).

\footnotetext{
16 This information was collected from the World Bank's World Development Indicators database.

17 The state ownership question asks, "The (Country) government, instead of the private sector, should own the most important enterprises and industries of the country. How much do you agree with this statement?". The inequality question asks, "The (Country) government should implement strong policies to reduce income inequality between the rich and the poor. To what extent do you agree or disagree with this statement?"

18 Urban, female gender, individual crime victimization, and household income deterioration are dummy variables. Age and skin tone are scaled to range from 0 to 1, with 0 being the lowest age and the lightest skin complexion and 1 being the highest observed age in the survey and very dark complexion respectively. Wealth ranges from 1 to 5 which represent the 5 wealth quintiles generated from items about ownership of household items in the survey. Education ranges from 0 to 3, with 0 indicating no schooling and 3 indicating post-secondary education. The two role of the state variables range from 0 to 1 with 1 being the most left-leaning response and 0 being the most rightleaning response.
} 
The results of the multi-level logistic analysis are presented in Table $1 .{ }^{19}$ The model in the first column includes, as the measure of economic context for the country, the proportion of individuals in a country whose households experienced income loss and the second column contains the measure of percent change in GDP per capita. ${ }^{20}$ Results across both are the same. Individuals who have experienced personal household economic loss are more likely to prioritize the economy over other issues, as are those who live in countries that have experienced more economic bad times (by either measure). Thus, both egotropic and sociotropic factors matter in predicting economic issue prioritization. Further, we see that the results for economic context are robust to alternative measures of economic conditions, affirming Singer (2010). Individuals on the economic left (by both measures, across both models) are more likely to prioritize the economy. Crime victims are less likely to do so and, while the contextual crime victimization measure is negative, it is not significant. Those living in rural areas, those who are younger, those with darker skin tones, women, those who are less educated, and those who are poorer are more likely to prioritize the economy. ${ }^{21}$

Table 1. Multilevel Logit Models of Economic MIP

\begin{tabular}{lcc}
\hline Variable & (a) & (b) \\
\hline Crime Victimization & $-0.098^{* * * *}$ & $-0.096 * * *$ \\
& $(0.021)$ & $(0.022)$
\end{tabular}

\footnotetext{
${ }^{19}$ Model (a) in Table 1 was estimated using the xtmelogit command in Stata 12. Model (b) in Table 1 was estimated using the xtlogit command in Stata12. A trade-off is made in using this approach, in that Stata 12 does not allow sampling weights to be included along with multilevel logit models. While this prevents us from applying survey weights, the multilevel approach allows us to both account for the nested structure of the data as well as explicitly model the effects of country-level factors.

20 The difference in the number of level-2 observations is a result of missing GDP per capita growth data for Argentina.

${ }^{21}$ In order to provide substantive interpretation of the main variables of interest, we generated a series of predicted probabilities from the model using the margins command in Stata 12 changing the variable of interest from the minimum to maximum values, holding other variables at their mean. Moving from a country where $12 \%$ of respondents report income deterioration (minimum) to a country where $42 \%$ report income deterioration leads to an increase in the probability of prioritizing the economy from $20 \%$ to $65 \%$. The two measures of economic leftist policy preferences produce more moderate results, with movement from the minimum to maximum on state ownership and inequality preferences leading to a $39 \%$ to $42 \%$ and a $37 \%$ to $42 \%$ increase in the probability of prioritizing the economy respectively.
} 
Household Income Deterioration

Greater Role of the State: Ownership

Greater Role of the State: Inequality

Urban

Female

Age

Skin Tone

Education Level

Wealth Quintile

Country-Year Crime Victimization

Country-Year Income Deterioration

GDP per capita growth (annual \%)

Intercept

Intercept Variance

$$
\begin{array}{cc}
0.240 * * * & 0.240 * * * \\
(0.019) & (0.020)
\end{array}
$$

$$
\begin{array}{cc}
0.102 * * * & 0.107 * * * \\
(0.025) & (0.026)
\end{array}
$$

$$
\begin{array}{cc}
0.189 * * * & 0.189 * * * \\
(0.034) & (0.035)
\end{array}
$$

$-0.148 * * *$

$$
\text { (0.020) }
$$

$0.083 * * *$

$0.0911^{* * *}$

(0.017)

(0.017)

$-0.394 * * *$

$-0.347 * * *$

(0.048)

(0.049)

$\begin{array}{cc}0.147 * * * & 0.124 * * \\ (0.054) & (0.055)\end{array}$

$-0.042 * * *$

$-0.101 * *$

(0.013)

(0.041)

$-0.098 * * *$

$-0.387 * * *$

(0.007)

(0.027)

$-3.257$

$-2.991$

(2.142)

(2.605)

$6.993 * * *$

(1.571)

$\begin{array}{cc}\cdot & -0.042 * * \\ -1.034 * * * & (0.017) \\ (0.483) & 0.0645 \\ & (0.646)\end{array}$

$0.287 * * *$

$0.329 * * *$ 
Cell entries are logit coefficients; standard errors in parentheses. $* * * \mathrm{p}<0.01, * * \mathrm{p}<0.05, * \mathrm{p}<0.1$, two-tailed

\section{Parliamentary Elites and Economic Issue Prioritization}

What about parliamentary elites? Do the issues that they place at the top of the agenda also reflect both economic context and ideological factors? To assess this, we make use of data from the Parliamentary Elites of Latin American (PELA) project by the University of Salamanca. We use data from the latest three rounds, which covers legislatures starting from 2000 to 2008, for a total of 30 surveys. $^{22}$ The PELA surveys contain a question that mirrors the AmericasBarometer question, asking legislators to identify "In your opinion as Representative, what is the most important problem that currently faces the [Country] government?" We coded responses to this measure using a scheme that corresponds to the one described above. In a multi-level logistic regression analysis, we include a measure of percent change in GDP per capita for the country in the year leading into the survey and, at the individual level, we include a measure of self-placement on the standard left-right dimension. ${ }^{23,24}$ While Latin American legislators vary in the policies they associate with left-right placement, attaching economic meanings to the left-right scale is more common at this level than among the mass public (see, e.g., Zechmeister 2010). While identical measures of economic ideology across the mass and elite models would be ideal, the assessment of the expectation that economic positioning matters requires only that the measures serve as a proxy for the same underlying concept. Left-right

\footnotetext{
${ }^{22}$ These 30 surveys cover 17 countries. These include three surveys from Mexico and El Salvador, two surveys from Guatemala, Honduras, Nicaragua, Costa Rica, Colombia, Ecuador, Bolivia, Chile, and the Dominican Republic, as well as a single survey from Panama, Peru, Paraguay, Uruguay, Brazil, and Argentina. In separate robustness checks we assessed whether the results hold if we also include surveys from previous waves (in which case Venezuela is also included), and find the results are the same.

${ }^{23}$ The model in Table 2 was estimated using the xtmelogit command in Stata 12.

${ }^{24}$ To account for potential partisan effects, we have also estimated a three-level model that includes a party-level random intercept. The results of the model are unchanged from those reported in Table 2.
} 
identification is measured in terms of a 10-point scale with 1 indicating the left end of the spectrum and 10 representing the right end. ${ }^{25}$ As in the mass public analyses, we include country fixed effects since countries are represented in the dataset multiple times. The results are presented in Table 2 and in Figure 2. As the table and figure show, both factors are significant, negative predictors of economic issue prioritization.

Table 2. Multilevel Logit Model of Elite Economic MIP

\begin{tabular}{lc}
\hline Variable & \\
\hline Left-Right Self-Placement & $-0.124 * *$ \\
& $(0.020)$ \\
GDP per capita growth (annual \%) & $-0.153^{* *}$ \\
& $(0.032)$ \\
Intercept & 0.545 \\
& $(0.352)$ \\
Intercept Variance & $0.282 * *$ \\
& $(0.061)$ \\
Level 1 Obs. & 2,679 \\
Level 2 Obs. & 30 \\
\hline $\begin{array}{l}\text { Cell entries are logit coefficients; standard errors in parentheses. Country } \\
\text { fixed effects included in the model but omitted from table. } \\
* * \text { p }<0.05, * \text { p }<0.1, \text { two-tailed }\end{array}$ \\
\hline
\end{tabular}

Figure $2 \mathrm{a}$ shows that the predicted likelihood of a legislator prioritizing the economy declines from over $85 \%$ to about $35 \%$ as we move across the empirical range on the measure of economic context: from a percent change in GDP per capita of -6 to +8 . In short, the average

25 The question asks, "As you remember, when talking about politics, the expressions left and right are normally used. On this card are a series of boxes that go from left to right. In which box would you place yourself taking into consideration your political ideas?" 
legislator is hyper-sensitive to economic decline; on the contrary, in better times, legislators shift in their priorities to other, non-economic issue areas. Figure $2 \mathrm{~b}$ shows the predicted likelihood that a legislator prioritizes the economy according to his or her placement on the left-right scale; all else equal, those to the far left are nearly 25 percentage points more likely to prioritize the economy than those on the right. ${ }^{26}$

\section{Figure 2. Elite Predicted $\operatorname{Pr}($ Economic MIP) as a Function of the State of the Economy and} Ideology

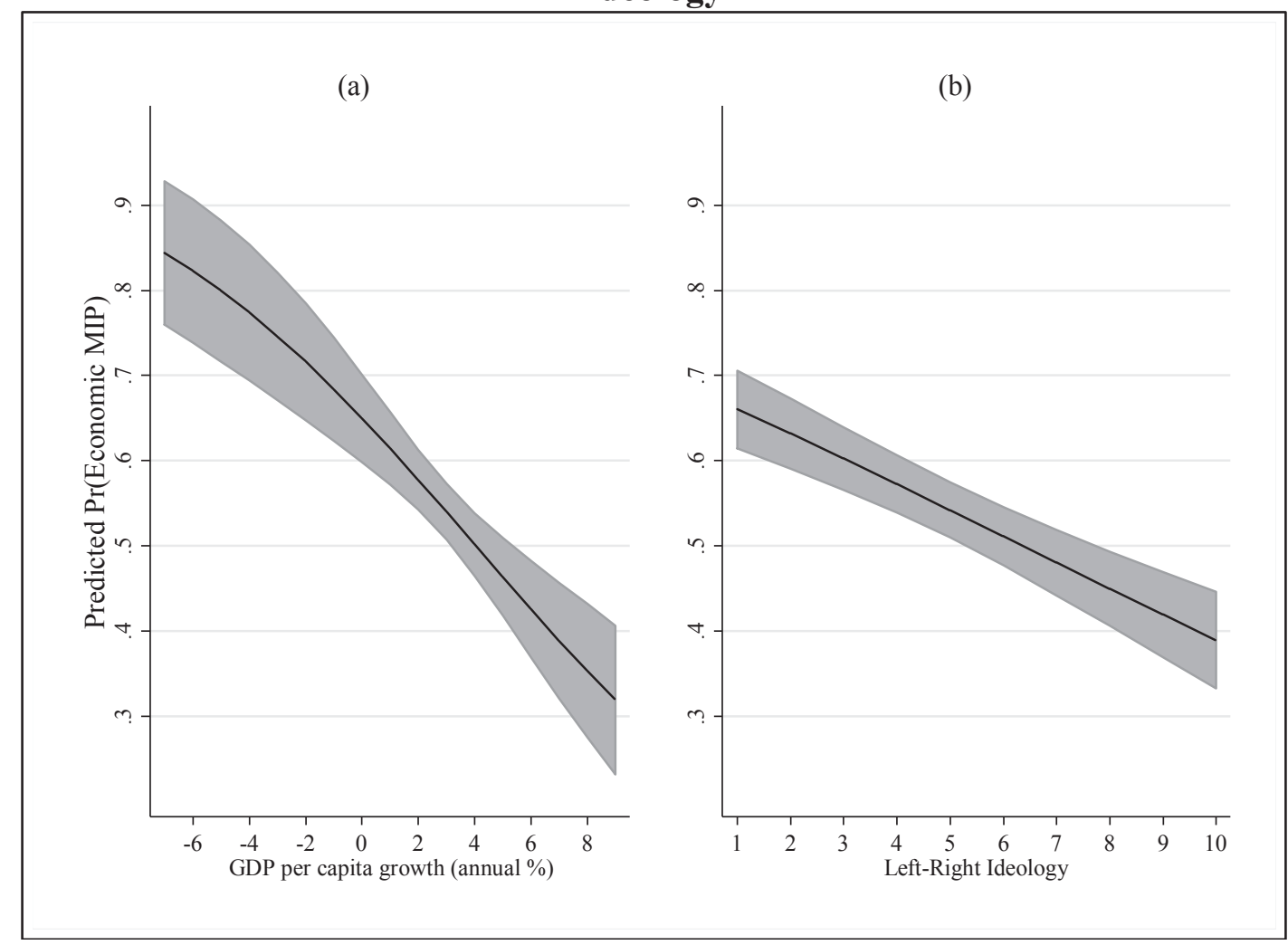

The general symmetry with respect to the predictors of economic issue prioritization across the mass public and elite models bodes well for representation in this domain. If both economic context and ideological positioning determine the extent to which citizens and their elected officials prioritize the economy over other issues, then we have reason to expect

${ }^{26}$ These figures were generated using the margins command in Stata 12. They represent the predicted probability of observing the outcome at different levels of the variable on the x-axis while holding the other variables at their mean values. 
congruence between elites and the mass public on economic issue prioritization. ${ }^{27}$ Yet, at the same time there is also reason to suspect that the presence of party branding dynamics could undermine a clear-cut tendency toward greater congruence on economic issue prioritization during bad times; that is, if certain parties are overly sensitive (and others insufficiently sensitive) to economic decline, then we may fail to find increased congruence under poor economic conditions. The next section addresses this topic, first presenting an assessment of absolute levels, and then an examination of the relationship between economic and ideological factors and economic issue priority congruence in Latin America.

\section{Economic Issue Priority Representation}

To now assess issue priority representation, we combine the AmericasBarometer mass data with the PELA elite data. All countries were included in the analysis for which there exist both AmericasBarometer and PELA data corresponding to that legislative term. Specifically, we matched the survey data to achieve the greatest correspondence between the implementation of the elite survey (typically when the new legislature takes office) and the mass survey (collected every two years). The matched data cover a span of time between 2004 and 2008. Of the 18 Latin American countries, Venezuela is not included in the following analyses because we did not have mass and elite that that corresponded for this time period. ${ }^{28}$

Figure 3 shows the percentage of parliamentary elites plotted against the percentage of the mass public who prioritize the Economy, for each country in the analysis. ${ }^{29}$ Superimposed onto this figure is a 45 degree dotted line. Points on this line represent the theoretically ideal instance in which elite issue prioritization is perfectly in line with the mass public. This line

\footnotetext{
${ }^{27}$ For another perspective, we also estimated the models of economic issue prioritization using the inflation rate (measured as the annual \% change in consumer prices) as an alternative measure of economic context. The results of these models are shown in Tables $1 \mathrm{~B}$ and $2 \mathrm{~B}$ in the appendix. While the effect of inflation is statistically significant and in the expected direction (positive) in the mass public model, the effect of inflation is not significant in the elite model. We also considered breaking the most important problem variable out into economic sub-categories; however, the analyses lose precision with such an approach because of the smaller number of observations in each analysis.

${ }^{28}$ For a table of the PELA and AmericasBarometer pairings used for this paper see the appendix.

${ }^{29}$ In order to ensure that the estimate of the percent of legislators prioritizing the economy is representative of the actual legislature, we weight the legislators' responses by their party's seat share in the chamber. This is necessary because the PELA surveys do not interview every legislator.
} 
therefore represents a normative standard from which to judge the different points. The figure reveals a significant positive correlation between elite and public issue prioritization, as reflected in the solid line of best fit. There is an important take-away from this analysis: generally speaking, levels of representation (or congruence) on economic issue prioritization are admirably high in the Latin American context, a finding that notably contrasts with documented weaknesses in policy stance-based assessments of party-supporter congruence (see Luna and Zechmeister 2005).

Figure 3. Relationship between Elite and Mass Issue Priorities: The Economy

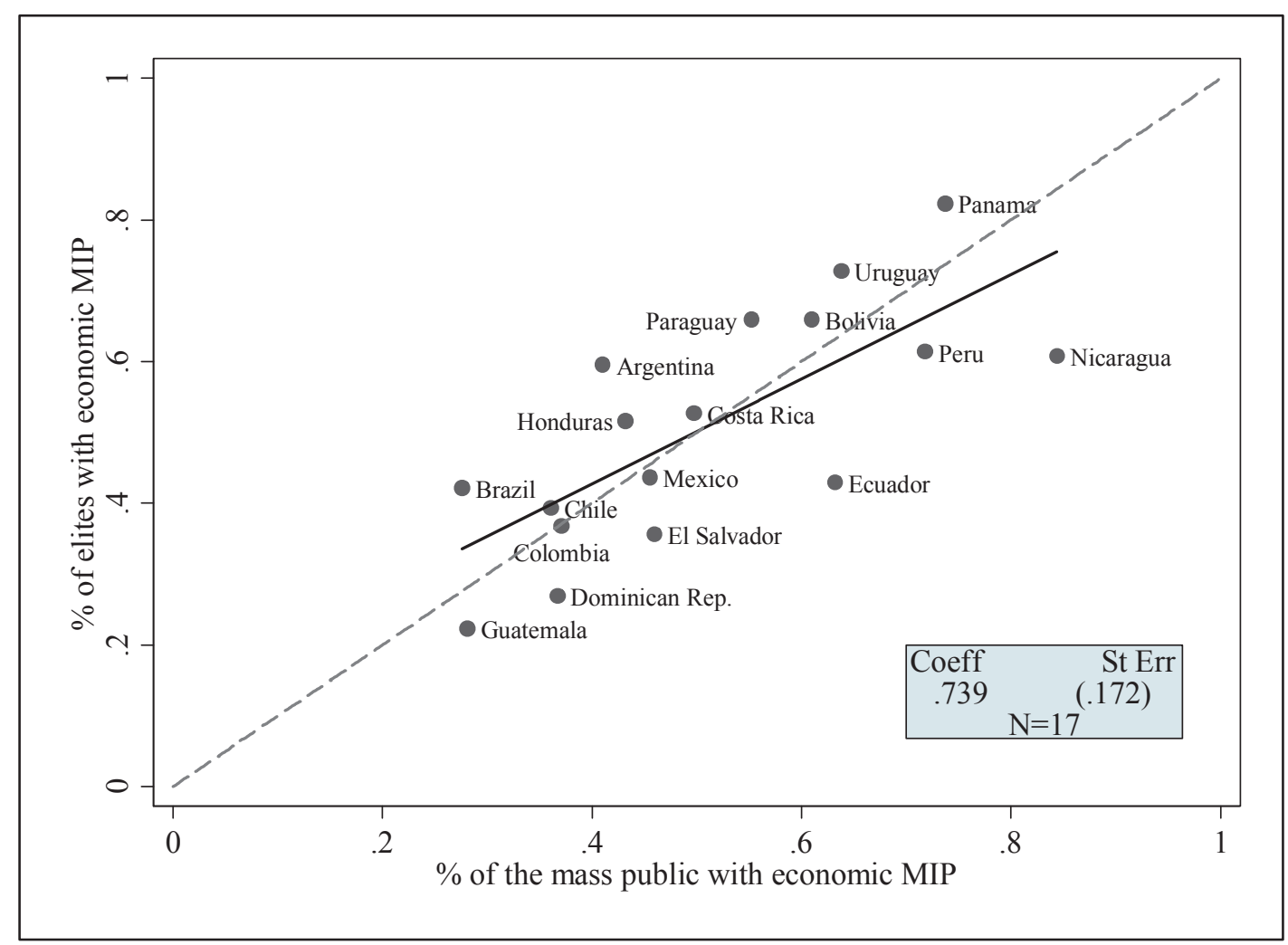

Economic and Ideological Predictors of Economic Issue Priority Representation

Elite and mass tendencies to prioritize the economy in Latin America are influenced by economic context and the dynamics of developing party brands linked to ideological profiles. As we demonstrated in earlier analyses, the economy rises as a priority in times of economic duress and 
those on the left are more likely to identify an economic issue as the most important problem facing the country. Given these influences, we expect to see that ideological and economic factors also relate to the level of economic issue priority representation (congruence) found in a given country or across parties.

In examining influences on economic priority representation, we rely on party-level measures of congruence, which are created by subtracting the percentage of party supporters in the mass public survey from the percentage of party members in the elite survey who prioritize the given issue. The difference between these provides an indicator of correspondence, with values closer to zero indicating greater congruence. ${ }^{30}$ Note that this is the simple difference between elite and mass issue prioritization and not the absolute value of the difference. This allows us to not only see the extent of elite-mass differences but also the direction of those differences.

We first assess variation in congruence across ideological tendencies - are they predictive of greater or lesser correspondence in economic issue priorities? To answer this question, we examine the relationship between a party's ideology and the extent to which party elites and their supporters in the mass public prioritize particular issues. ${ }^{31}$ We measure a party's ideology as the mean self-placement among the party's legislators in each survey on a 10-point left-right scale. Figure 4 plots the difference between elite and mass economic issue prioritization (at the party

\footnotetext{
${ }^{30}$ For most countries, party supporters are identified using an item about partisan identification, yet that question is not included in some AmericasBarometer surveys. For Panama 2004, we rely on an item asking respondents with which party they are registered. For Colombia and Bolivia 2006, we rely on a legislative and presidential vote choice item respectively. Brazil is omitted from the party level analyses since the presidential vote choice question cannot be accurately used to differentiate partisans due to coalition formation in that race. For Paraguay 2006, we note that the party identification measure was not preceded by the yes/no "do you identify with any political party" filter that is generally standard in the AmericasBarometer; as a result, reported partisanship is higher for that case than would be expected if the instrument were identical (see Blais et al. 2001). Following Luna and Zechmeister (2005), we restrict our analyses to cases with at least 15 party supporters and 3 party elites from each survey.

${ }^{31}$ In the party-level analyses that follow, we utilize a weighting scheme to correct for two possible issues. One is that the sample may marginally over-represent more fragmented systems (which therefore have more parties in the data). To address this, we create a weight that treats every country as though it had three parties in the dataset under analysis (three is the median value of parties in the sample). The second issue concerns whether less precisely estimated measures of economic prioritization at the party level should have equal weight. To discount less certain estimates, we created the following weight: , where is the standard error of the proportion prioritizing the economy among mass partisans and is the standard error of the proportion prioritizing the economy among elite partisans. This down weights cases with less precisely estimated proportions of partisans prioritizing the economy. The final weight is simply the product of the two weights. The results depicted here are based on analyses using this weight variable; however, the findings are the same if instead we do not apply the weight measure.
} 
level) and the party's mean ideological self-placement. ${ }^{32}$ The pattern that emerges reveals that leftist parties tend to over-prioritize economic issues relative to their supporters and right wing parties tend to under-prioritize economic issues relative to their supporters. This result resonates with predictions that emerge from the issue ownership paradigm, where parties actively work to stake out issue domains as unique to their agendas and competencies (Petrocik 1996; Petrocik, Benoit, and Hansen 2003). Baker and Greene (2011), among others, hold that the political left has a clear economic policy mandate among Latin American voters. In this context, the issue ownership school would predict that right wing party elites are likely to downplay economic issues and the left will emphasize them. The result of such strategic maneuvering would be that these types of parties will either under- or over-prioritize economic problems relative to their supporters, which is exactly what we see in Figure 4.

Figure 4. Party Ideology and Issue Priority Congruence

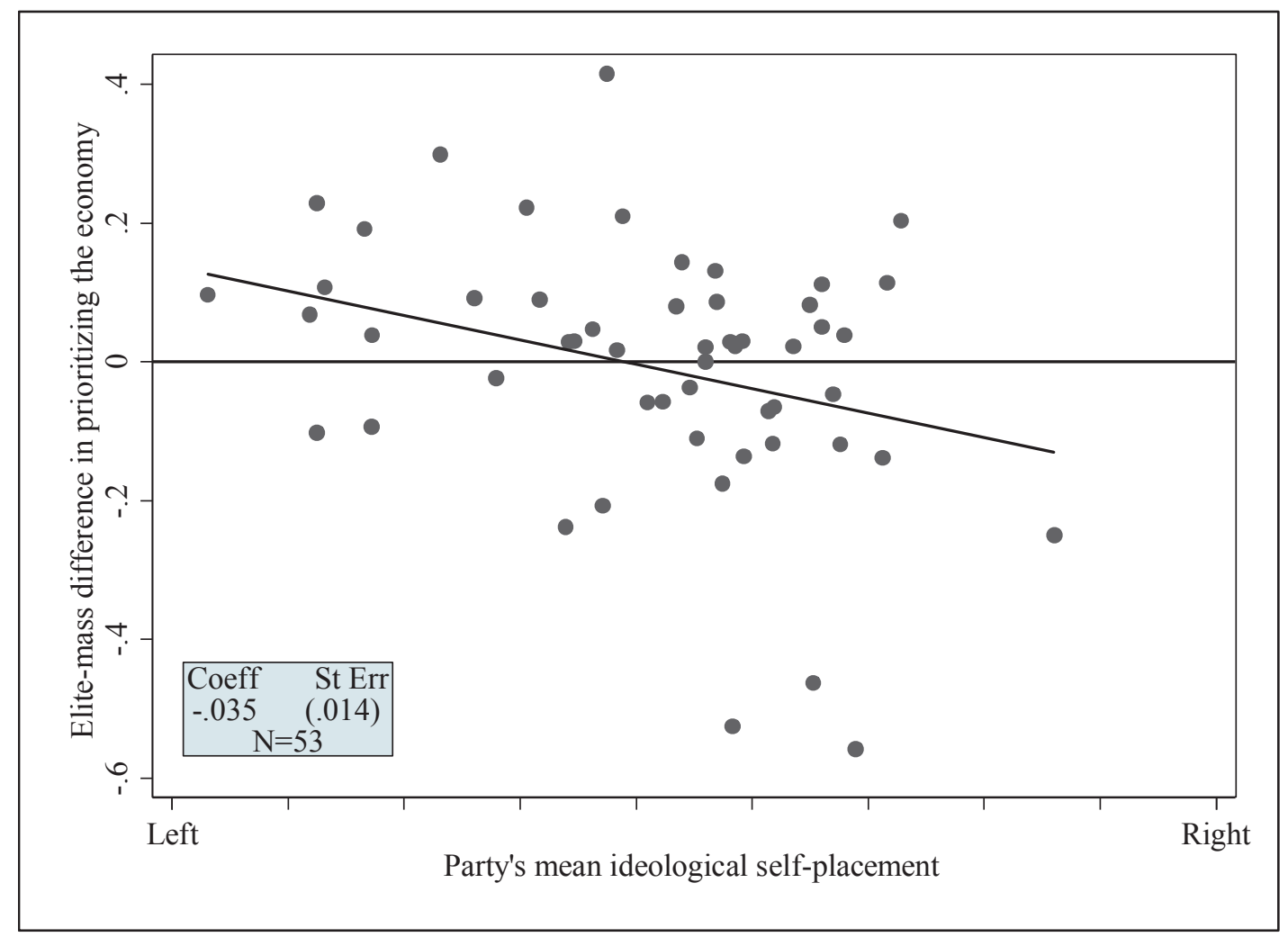

\footnotetext{
${ }^{32}$ Note that this figure includes the same sample of LAPOP and PELA surveys as in Figure 3, with the exception of Brazil. In this case, the available items in the surveys did not allow for matching partisan supporters with party elites. See Appendix A for a list of the LAPOP and PELA surveys used for this section of the paper.
} 
How does this pattern in ideological profiles play out across different levels of aggregate economic performance? Williams, Seki, and Whitten (2016) argue that parties give comparatively more emphasis to economic downturns in campaigns conditional on their governing status, their role in economic policymaking, and the behavior of ideologically proximate parties. Our expectation also rests on the notion that the ideological branding of parties shapes responses to economic conditions. If leftist parties in the region have worked to develop ownership over economic issues in comparison to their opponents on the right, then we expect these differences to be magnified in economic hard times. Figure 5 plots the differences between elite and mass prioritization of the economy and the change in GDP per capita growth. In order to discern the influence of ideological profiles in the relationship between issue priority representation and economic performance, parties are divided into three groups. Left and right parties are those which are in the bottom and top quartiles in the empirical range of mean selfplacement, respectively. Center parties refer to those in the middle two quartiles of mean ideological self-placement. The pattern that emerges is a notable divergence between right-wing parties and those on the left and center, particularly in cases where the economy is performing poorly. Specifically, when economic performance is mediocre to poor, parties on the right (diamonds) are more likely to under-represent economic issue prioritization (relative to their party supporters), while those in the center (dots) and on the left (marked by an x) give more weight to the economy as the most important issue (relative to their supporters).

\section{Figure 5. Economic Issue Priority Congruence and the State of the Economy}




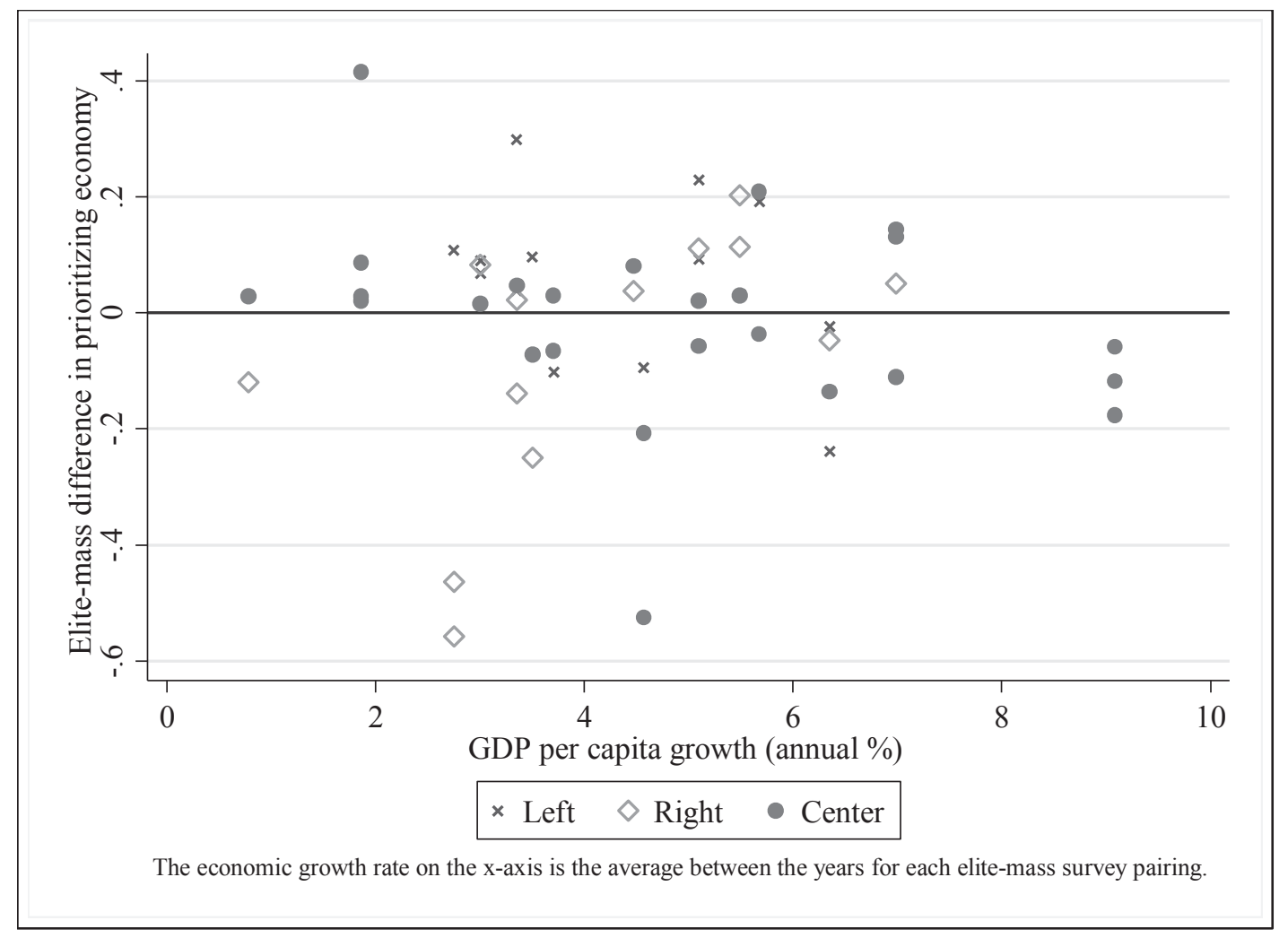

To further examine this interactive relationship between ideology and the state of the economy, we model elite-mass difference in economic prioritization as a function of the party's mean ideological position, GDP per capita growth, and their interaction. A hierarchical model is employed since parties are nested within countries. Table 3 shows the results of this model. ${ }^{33}$

Table 3. Multilevel Model of Elite-Mass Economic Priority Differences

\begin{tabular}{ll}
\hline Variable & $-0.111^{* *}$ \\
\hline Mean Left-Right Self-Placement of Party & $(0.044)$ \\
& $-0.088^{*}$ \\
GDP per capita growth (annual \%) & $(0.049)$ \\
& \\
model was estimated using the xtmixed command on STATA 12. Note that the number of party-level \\
ons (51) does not match the number reported in Figure 4 since Argentine parties are excluded for lack of
\end{tabular}

33 This model was estimated using the xtmixed command on STATA 12. Note that the number of party-level observations (51) does not match the number reported in Figure 4 since Argentine parties are excluded for lack of GDP data. Venezuela and Brazil also are not included in these analyses (see text on page 14 and footnote 30). 
Left-Right Placement X GDP per

capita growth

Intercept

Intercept Variance

Level 1 Obs.
$0.016^{*}$

$0.571 * *$

$0.123 * *$

$(0.025)$

15

Standard errors in parentheses. Of the 18 Latin American countries, Argentina, Brazil, and Venezuela are excluded (see footnote 30 ). $* * \mathrm{p}<0.05, * \mathrm{p}<0.1$, two-tailed

In order to provide a substantive interpretation of the model's interactive effect, we plot the predicted difference between elite and mass prioritization of the economy across the range of economic performance for a party with a mean left-right placement at 2 and a party with a mean placement at 8. Figure 6 demonstrates this interactive effect. When the economy is faring comparatively poorly, parties on the left and right have asymmetric responses relative to their supporters in the mass public. In particularly hard economic times, the left-wing and the rightwing party elites prioritize the economy approximately 30 percentage points more and less, respectively, in comparison to their supporters. Only when the economy is doing relatively well, do parties on either side of the ideological spectrum begin to more closely resemble each other and their supporters. ${ }^{34}$ In short, though both the mass public and parliamentary elites are sensitive to shifting economic conditions, the tendencies of parties on the left (and center, per

\footnotetext{
34 Theoretically, an alternative explanation for the effects of party ideology could be that the over- and underemphasis we observe is actually the result of a party's status as part of the government or opposition. In this case, the observed leftist over-emphasis is a result of many leftist incumbents during the time period we examine. If this explanation is correct, then re-running the model in Table 3and replacing party ideology with incumbency should yield similar results in terms of diverging over and under emphasis in hard economic times. Table $1 \mathrm{C}$ and Figure $1 \mathrm{C}$ in the appendix demonstrate that this is not the case: we find no interactive effect between economic context and incumbency status.
} 
Figure 5), versus the right, to over-emphasize (versus under-emphasize) economic issues in poor economic times prevents a strengthening of economic issue prioritization. ${ }^{35,36}$

Figure 6. The Effect of Economic Context Conditional on Party Ideological Profile

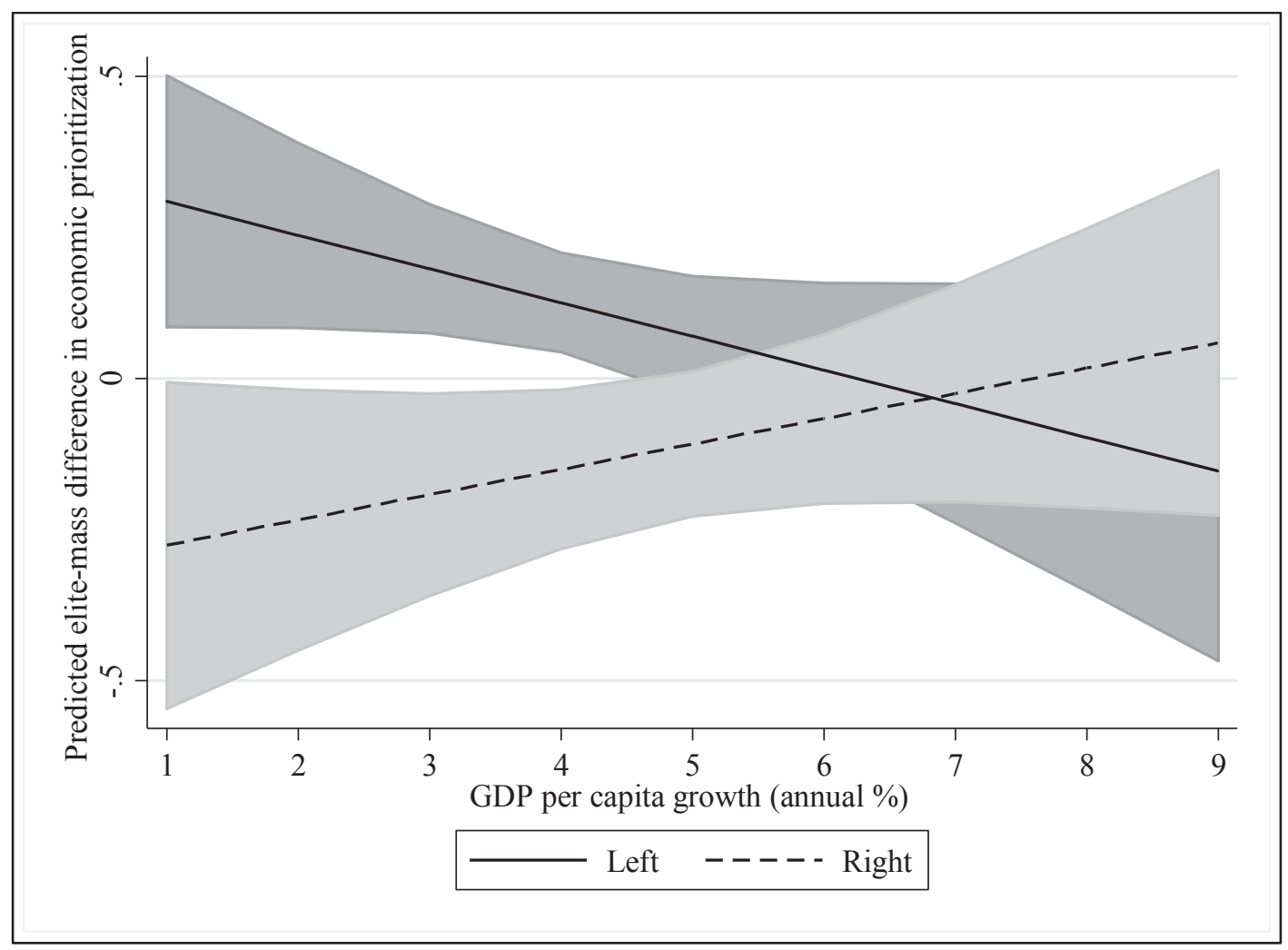

\section{Conclusion}

Politicians campaign on promises to resolve problems and generate positive outcomes. Voters are responsive to these appeals and often assess politicians on the basis of their performance, over and above what are often meager considerations of policy stances. To the extent this is the case, issue priority representation is a meaningful and important form of representation to examine and

\footnotetext{
${ }^{35}$ Since we have a limited number of second-level observations in the model for Table 3, we conducted a sensitivity analysis to ensure that the inclusion or exclusion of a single country does not significantly determine our results and conclusions. This sensitivity analysis is reported in Table 1D in the appendix. It shows the coefficients and standard errors for the three variables of interest as the parties from each country are removed from the analysis. While the confidence intervals fluctuate, the sign and general magnitude of the coefficients remain consistent throughout. Not included for the purpose of parsimony are the replications of Figure 6 for each model that demonstrate substantively similar results (divergence in hard economic times).

${ }^{36}$ As with the models of economic prioritization, we also estimated the model of priority differences using inflation as an alternative measure of economic context. Appendix Table 3B and Figure 1B replicate Table 3 and Figure 6 using the inflation measure. The results are substantively identical to those reported above. Leftist and rightist parties over- and under- emphasize the economy, respectively, in times of high inflation.
} 
assess across many democracies, and particularly in Latin America. We find that both economic conditions - fat and lean times - and branding dynamics (ownership of policy areas tied to ideological families) predict the extent to which the general public and elected legislators prioritize the economy. With respect to economic factors, both elites and the mass public respond to the aggregate economic situation in similar ways, placing greater emphasis on the economy during hard times. For the mass public, such hard times matter at the individual level as well.

When it comes to economic issue priority representation, levels are generally quite high in Latin America. From the perspective of democratic quality and politician responsiveness, this is a positive and welcome outcome. Our work shows that it is frequently the case that the legislature's degree of emphasis on economic issues closely aligns with the extent to which the public believes the economy should dominate the national agenda. This is an important finding, in that it demonstrates that there exists more responsiveness (or, at the least, apparent responsiveness) by political elites to the voting public than a narrow focus on policy-based representation alone would suggest. Issue priority representation is not a rival or substitute for policy-based representation. Yet to the degree that policy-based representation can be challenging to attain in high volumes in general and, in particular, in Latin America, it is encouraging to find fairly high levels of congruence on issue priorities between elected officials and their voting publics. To put it simply, we find that Latin American party systems tend to reflect the substance of the economic mandates assigned to them by the public.

Elite responsiveness to public opinion and party competition is further evident in the fact that leftist parties tend to give comparatively more priority to the economy, suggesting they are motivated to establish brand identities and signal their "ownership" with respect to economic issues. When it comes to the interaction between economic conditions and mean ideological placement of the parties, we find branding mechanisms also at play here. These further influence the nature of economic issue priority representation in the Latin American region by way of leading leftist and centrist parties to over-emphasize economic issues in times of decline and rightist parties to under-emphasize these issues. That tendency for leftist and centrist parties to strongly emphasize economic issue prioritization in economic downtimes may be one reason for the appeal that left parties and candidates demonstrated with the voting public during the so- 
called pink tide years, in which a wave of left-leaning candidates came to power in Latin America beginning in 2000 in the wake of perceived failures of the neoliberal model to fulfill its economic promise. Scholars have debated whether the pink tide came about because of an ideological shift to the left or pure retrospective economic voting (see, e.g., Baker and Greene 2011; Murillo, Oliveros, and Vaishnav 2010; Queirolo 2013); our work here suggests a third mechanism could be the left's successful selling of their brand as one that gives significant priority to the economy. Future research on the electoral - and economic - implications of overand under-representation of economic issue prioritization is certainly warranted. Sticking more closely to what our analyses document, we conclude that these tendencies explain the fact that economic priority representation as a whole does not increase in step with economic decline: party branding dynamics tamp down on an increase in issue priority representation in economic downtimes. Notably, though, base levels of economic issue prioritization representation are comparatively high, thus reducing concerns about normative implications of a failure to find greater alignment (correspondence, or representation) in economic bad times. 


\section{Works Cited}

Abramson, Paul R., John H. Aldrich, and David W. Rohde. 1999. Change and continuity in the 1996 and 1998 elections. Washington, D.C.: Congressional Quarterly Press.

Achen, Christopher H., and Larry M. Bartels. 2016. Democracy for realists: Why elections do not produce responsive government. Princeton, NJ: Princeton University Press.

Adams, James. 2001. Party competition and responsible party government. Ann Arbor, MI: University of Michigan Press.

Alcántara Sáez, Manuel. Proyecto de Élites Parlamentarias Latinoamericanas (PELA). University of Salamanca.

Alvarez, R. Michael, and Jonathan Nagler. 2004. Party system compactness: Measurement and consequences. Political Analysis 12(1): 46-62.

The AmericasBarometer by the Latin American Public Opinion Project (LAPOP), www.LapopSurveys.org.

Baker, Andy, and Kenneth F. Greene. 2011. The Latin American left's mandate: Free-market policies and issue voting in new democracies. World Politics 63 (10): 43-77.

Baker, Andy, and Kenneth F. Greene. 2015. Positional issue voting in Latin America. Chapter 7 in Ryan E. Carlin, Matthew M. Singer, and Elizabeth J. Zechmeister (Eds.), The Latin American Voter: Pursuing Representation and Accountability in Challenging Contexts (Ann Arbor, MI: University of Michigan Press), pp. 173-194.

Blais, André, Elisabeth Gidengil, Richard Nadeau, and Neil Nevitte. 2001. "Measuring party identification: Britain, Canada, and the United States." Political Behavior 23(1): 5-22.

Boas, Taylor C. 2016. Presidential Campaigns in Latin America: Electoral Strategies and Success Contagion. New York: Cambridge University Press.

Budge, Ian. 1993. "Issues, Dimensions, and Agenda Change in Postwar Democracies." Chapter in William H. Riker (Ed.), Agenda Formation. Ann Arbor, MI: University of Michigan Press.

Budge, Ian, and Dennis J. Farlie. 1983. Explaining and Predicting Elections: Issue Effects and Party Strategies in Twenty-Three Democracies. Boston: Allen \& Unwin. 
Campbell, Angus, Philip E. Converse, Warren E. Miller, and Donald E. Stokes. 1960. The American voter. New York: John Wiley \& Sons.

Carlin, Ryan E., Matthew M. Singer, and Elizabeth J. Zechmeister, Eds. 2015. The Latin American voter. Pursuing representation and accountability in challenging contexts. Ann Arbor, MI: University of Michigan Press.

Converse, Philip E. 1964. The nature of belief systems in mass publics. In David E. Apter (Ed.), Ideology and its discontents. New York: Free Press. 206-261.

Cunow, Saul. 2014. More is less (representation): Choice set size, information acquisition, and correct voting in multimember districts. Paper presented at the Making Electoral Democracy Work Voting Experiment Workshop, Montreal Canada, March 28-29. http://electoraldemocracy.com/montreal-voting-experiment-workshop-1514

Dow, Jay. 1998. A spatial analysis of the 1989 Chilean presidential election. Electoral Studies 17(1): $61-76$.

Downs, Anthony. 1957. An Economic Theory of Democracy. New York, NY: Harper and Row.

Fiorina, Morris P. 1981. Retrospective voting in American national elections. New Haven, CT: Yale University Press.

Gélineau, Francois, and Matthew M. Singer. 2015. The economy and incumbent support in Latin America." Chapter in Ryan E. Carlin, Matthew M. Singer, and Elizabeth J. Zechmeister (Eds.), The Latin American voter: Pursuing representation and accountability in challenging contexts (Ann Arbor, MI: University of Michigan Press), pp. 281-299.

Hart, Austin. 2013. "Can candidates activate or deactivate the economic vote? Evidence from two Mexican elections." Journal of Politics 75 (4): 1051-1063.

Helmke, Gretchen. Forthcoming. Institutions on the Edge: Inter-branch crises in Latin America. New York: Cambridge University Press.

Jones, Bryan D., and Frank R. Baumgartner. 2004. Representation and agenda setting. The Policy Studies Journal 32(1): 1-24.

Kinder, Donald R. and D. Roderick Kiewiet. 1979. Economic discontent and political behavior: the role of personal grievances and collective economic judgments in congressional voting. American Journal of Political Science 23 (3): 495-527. 
Kinder, Donald R. and D. Roderick Kiewiet. 1981. Sociotropic politics: The American case. British Journal of Political Science 11 (2): 129-161.

Kitschelt, Herbert, Kirk A. Hawkins, Juan Pablo Luna, Guillermo Rosas, and Elizabeth J. Zechmeister. 2010. Latin American party systems. New York: Cambridge University Press.

Lewis-Beck, Michael S. 1988. Economics and elections: The major western democracies. Ann Arbor, MI: University of Michigan Press.

Lewis-Beck, Michael S., and Martin Paldam. 2000. Economic voting: An introduction. Electoral Studies 19: 113-121.

Levitsky, Steven, and Kenneth M. Roberts (Eds.). 2011. The Resurgence of the Latin American Left. Baltimore, MD: Johns Hopkins.

Londregan, John B. 2000. Legislative institutions and ideology in Chile. New York: Cambridge University Press.

Luna, Juan Pablo and Elizabeth J. Zechmeister. 2005. Representation in Latin America: A study of elite-mass congruence in 9 countries. Comparative Political Studies 38(4): 388-416.

Lupu, Noam. 2016. Party brands in crisis: Partisanship, brand dilution, and the breakdown of political parties in Latin America. New York: Cambridge University Press.

Madison, James. Federalist 10.

Mainwaring, Scott and Edurne Zoco. 2007. Political sequences and the stabilization of interparty competition: Electoral volatility in old and new democracies. Party Politics 13 (2): 155-178.

Manin, Bernard, Adam Przeworski, and Susan C. Stokes. 1999. Elections and representation. Chapter 1 in Przeworski, Adam, Susan Stokes, and Bernard Manin, Eds. Democracy, accountability, and representation. New York: Cambridge University Press. 
Morgan, Jana. 2011. Bankrupt representation and party system collapse. Philadelphia, PA: Penn State University Press.

Murillo, María Victoria, Virginia Oliveros, and Milan Vaishnav. 2010. Electoral revolution or democratic alternation? Latin American Research Review 45(3): 87-114.

Neundorf, Anja, and James Adams 2016. What this election is about: Party competition and the reciprocal effects of German citizens' issue priorities and party attachments, 1984-2009. British Journal of Political Science. Available on CJO 2016 doi:10.1017/ S0007123415000642.

Page, Benjamin I. 1978. Choices and echoes in presidential elections: Rational man and electoral democracy. Chicago: University of Chicago Press.

Page, Benjamin I., and Richard A. Brody. 1972. Policy voting and the electoral process: The Vietnam issue. American Political Science Review 66(3): 979-88.

Petrocik, John R. 1996. Issue ownership in presidential elections, with a 1980 case study. American Journal of Political Science 40 (3): 825-850.

Petrocik, John R., W.L. Benoit, and G.J. Hansen. 2003. Issue ownership and presidential campaigning, 1952-2000. Political Science Quarterly 118(4): 599-626.

Pitkin, Hanna F. 1967. The concept of representation. Berkeley, CA: University of California Press.

Powell, G. Bingham, Jr. 2004. Political representation in comparative politics. Annual Review of Political Science 7: 273-296.

Queirolo, Rosario. 2013. The success of the left in Latin America: Untainted parties, market reforms, and voting behavior. Notre Dame, IN: University of Notre Dame Press.

Saiegh, Sebastian M. 2015. Using Joint Scaling Methods to Study Ideology and Representation: Evidence from Latin America. Political Analysis 23(3): 363-384.

Samuels, David, and Matthew Shugart. 2003. Presidentialism, elections, and representation. Journal of Theoretical Politics 15(10): 33-60. 
Samuels, David, and Matthew Shugart. 2006. Presidents, prime ministers, parties, and mandaterepresentation: A global test. Paper prepared for the annual meeting of the American Political Science Association (APSA), Philadelphia. http://www.polisci.umn.edu/ dsamuels/Samuels\%20Shugart\%20APSA\%202006b.pdf

Shepsle, Kenneth A. 1972. The strategy of ambiguity: Uncertainty and electoral competition. American Political Science Review 66(2): 555-568.

Singer, Matthew M. 2010. Who says "It's the economy"? Cross-national and cross-individual variation in the salience of economic performance. Comparative Political Studies 44 (3): 284-312.

Stokes, Donald E. 1963. Spatial models of party competition. American Political Science Review 57 (2): 368-377.

Stokes, Susan C. 1999. What do policy switches tell us about democracy? Chapter 3 in Przeworski, Adam, Susan Stokes, and Bernard Manin, Eds., Democracy, accountability, and representation. New York: Cambridge University Press.

Vavreck, Lynn. 2009. The message matters: The economy and presidential campaigns. Princeton, NJ: Princeton University Press.

Williams, Laron K., Katsunori Seki, and Guy D. Whitten. 2016. You've got some explaining to do: The influence of economic conditions and spatial competition on party strategy. Political Science Research and Methods 4(1): 47-63.

Wlezien, Christopher. 2005. On the salience of political issues: The problem with 'most important problem'. Electoral Studies 24: 555-579.

Zechmeister, Elizabeth J. 2008. Policy-based voting, perceptions of issue space, and the 2000 Mexican elections. Electoral Studies 27(4): 649-660.

Zechmeister, Elizabeth J. 2010. Left-right semantics as a facilitator of programmatic structuration. Chapter 3 in Herbert Kitschelt, Kirk A. Hawkins, Juan Pablo Luna, Guillermo Rosas, and Elizabeth J. Zechmeister. Latin American party systems. New York: Cambridge University Press.

Zechmeister, Elizabeth J. 2015. Left-right identifications and the Latin American voter. Chapter 8 in Ryan E., Carlin, Matthew M. Singer, and Elizabeth J. Zechmeister (Eds). The Latin 
American voter: Pursuing representation and accountability in challenging contexts. Ann Arbor, MI: University of Michigan Press.

Zechmeister, Elizabeth J., and Margarita Corral. 2013. Individual and contextual constraints on ideological labels in Latin America. Comparative Political Studies 46(6): 675-701. 


\section{Appendix [Included for Reviewers; To be Place Online]}

Table 1A. Time Frame of the Survey Data Used in the Paper (Matched Analyses)

\begin{tabular}{|c|c|c|}
\hline Country & $\begin{array}{c}\text { Legislative Period in PELA } \\
\text { Survey }\end{array}$ & AmericasBarometer Survey \\
\hline Argentina & $2007-11$ & 2008 \\
\hline Bolivia & $2006-10$ & 2006 \\
\hline Brazil & 2003-07 & 2006 \\
\hline Chile & 2006-10 & 2006 \\
\hline Colombia & 2006-10 & 2006 \\
\hline Costa Rica & 2006-10 & 2006 \\
\hline Ecuador & 2007-08 & 2008 \\
\hline El Salvador & 2006-09 & 2006 \\
\hline Guatemala & $2008-12$ & 2008 \\
\hline Honduras & $2006-10$ & 2006 \\
\hline Mexico & 2006-09 & 2006 \\
\hline Nicaragua & $2007-11$ & 2008 \\
\hline Panama & 2004-09 & 2004 \\
\hline Paraguay & 2003-08 & 2006 \\
\hline Peru & $2006-11$ & 2006 \\
\hline Dominican Republic & $2006-10$ & 2006 \\
\hline Uruguay & $2005-10$ & 2006 \\
\hline
\end{tabular}


Table 1B. Multilevel Logit Model of Mass Public Economic MIP (Using Inflation)

Variable

Crime Victimization

$-0.098 * * *$

$(0.021)$

Household Income Deterioration

$0.241 * * *$

(0.019)

Role of the State (Ownership)

$0.103^{* * *}$

$(0.025)$

Role of the State (Inequality)

$0.188^{* * *}$

$(0.034)$

Urban

$-0.150 * * *$

$(0.020)$

Female

$0.083^{* * *}$

(0.017)

Age

$-0.395^{* * *}$

$(0.048)$

Skin Tone

$0.146^{* * *}$

(0.054)

Education Level

$-0.125 * * *$

$(0.040)$

Wealth Quintile

$-0.391 * * *$

(0.026)

Country-Year Crime Victimization

1.014

(2.304)

Inflation, Consumer Prices (annual \%)

$0.051 * *$ 
$(0.021)$

Intercept

$-1.068^{*}$

$(0.579)$

Intercept Variance

$0.338^{* * *}$

$(0.034)$

Level 1 Observations

66,181

Level 2 Observations

52

Cell entries are logit coefficients; standard errors in parentheses.

$* * * \mathrm{p}<0.01, * * \mathrm{p}<0.05,{ }^{*} \mathrm{p}<0.1$ 
Table 2B. Multilevel Logit Model of Elite Economic MIP (Using Inflation)

\begin{tabular}{lc}
\hline Variable & $-0.121^{* *}$ \\
\hline Left-Right Self-Placement & $(0.020)$ \\
& 0.007 \\
Inflation, Consumer Prices (annual \%) & $(0.043)$ \\
& 0.126 \\
Intercept & $(0.784)$ \\
& $0.422 * *$ \\
Intercept Variance & $(0.070)$ \\
& 2,789 \\
Level 1 Obs. & 31 \\
Level 2 Obs. & \\
\hline Cell entries are logit coefficients; standard errors in parentheses. Country \\
fixed effects included in the model but omitted from table. \\
$* *$ p $<0.05, * \mathrm{p}<0.1$
\end{tabular}

Table 3B. Multilevel Model of Elite-Mass Economic Priority Differences (Using Inflation)

\begin{tabular}{lc} 
Variable & \\
\hline Mean Left-Right Self-Placement & 0.004 \\
& $(0.013)$ \\
Inflation, Consumer Prices (annual \%) & $0.039^{* *}$ \\
& $(0.012)$ \\
Left-Right Placement X Inflation & $-0.009^{* *}$ \\
& $(0.001)$ \\
Intercept & 0.028
\end{tabular}


Intercept Variance

$0.117 * *$

$(0.024)$

Level 1 Obs.

53

Level 2 Obs.

16

Standard errors in parentheses. $* * p<0.05, * \mathrm{p}<0.1$ 
Figure 1B. The Effect of Economic Context Conditional on Party Ideological Profile (Using Inflation)

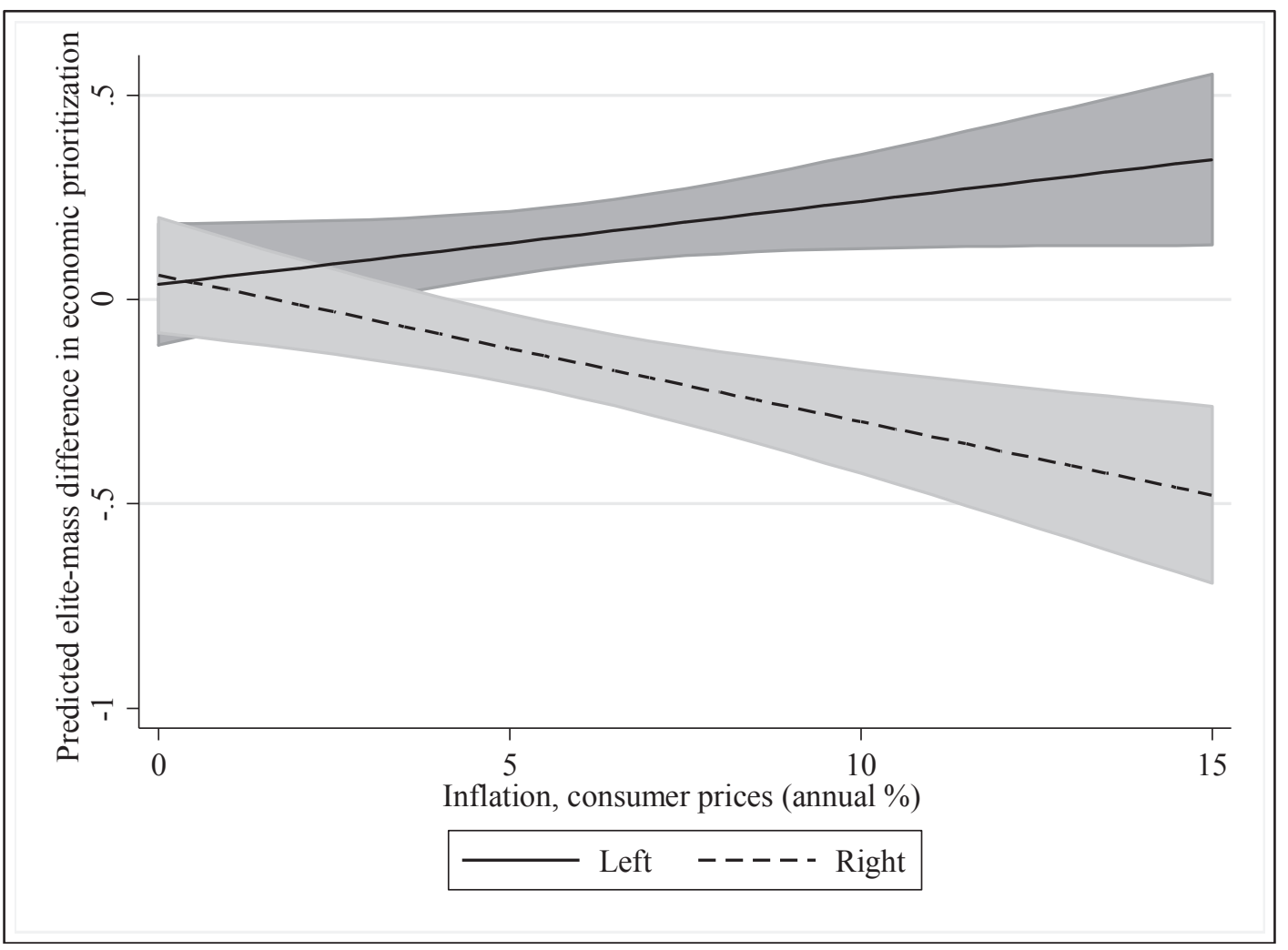

Table 1C. Multilevel Model of Elite-Mass Economic Priority Differences Replacing Party Ideology with Incumbency Status

Variable

Incumbent Party Status

0.114

$(0.129)$

GDP per capita growth (annual \%)

Incumbent Status X GDP per $-0.009$ capita growth (0.019)

Intercept $-0.062$

Intercept Variance

$0.100^{* *}$ 
Level 2 Obs.

Standard errors in parentheses. $* * \mathrm{p}<0.05, * \mathrm{p}<0.1$

Parties were coded as an incumbent if they were the party of the sitting president or part of the president's electoral coalition. 
Figure 1C. The Effect of Economic Context (Not) Conditional on Party Incumbency Status

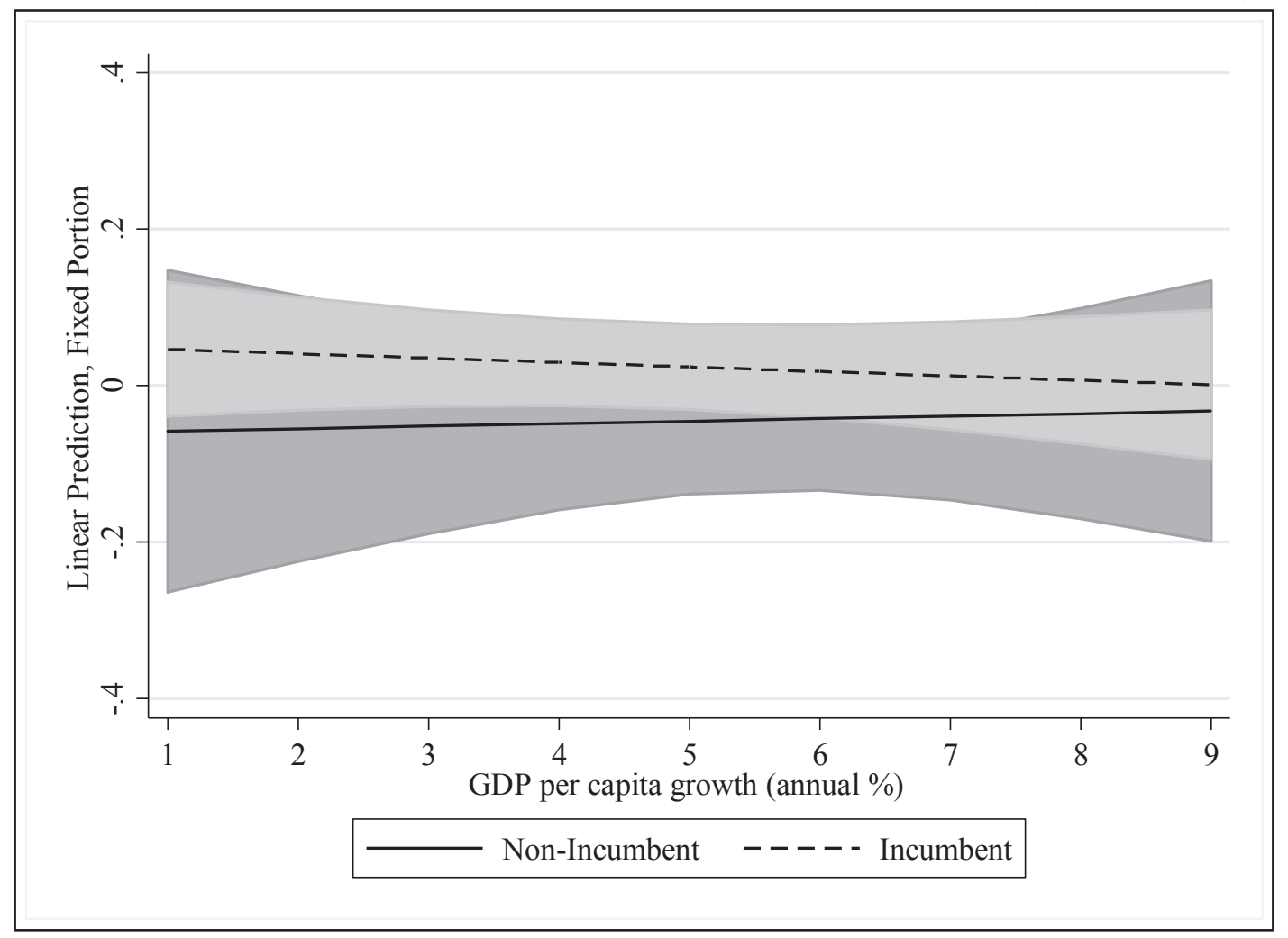


Table 1D. Sensitivity Analysis

\begin{tabular}{|c|c|c|c|}
\hline Country Excluded & $\begin{array}{l}\text { GDP per capita } \\
\text { growth (annual \%) }\end{array}$ & $\begin{array}{l}\text { Mean Left-Right } \\
\text { Placement }\end{array}$ & $\begin{array}{l}\text { GDP growth X } \\
\text { Left-Right Placement }\end{array}$ \\
\hline Mexico & $\begin{array}{l}-.090^{*} \\
(.048)\end{array}$ & $\begin{array}{l}-.118^{* *} \\
(.044)\end{array}$ & $\begin{array}{l}.016^{*} \\
(.009)\end{array}$ \\
\hline Guatemala & $\begin{array}{l}-.109 * \\
(.063)\end{array}$ & $\begin{array}{l}-.128 * * \\
(.058)\end{array}$ & $\begin{array}{l}.020 \\
(.012)\end{array}$ \\
\hline El Salvador & $\begin{array}{l}-.092^{*} \\
(.052)\end{array}$ & $\begin{array}{l}-.117 * * \\
(.051)\end{array}$ & $\begin{array}{l}.017^{*} \\
(.010)\end{array}$ \\
\hline Honduras & $\begin{array}{l}-.087 * \\
(.050)\end{array}$ & $\begin{array}{l}-.111 * * \\
(.044)\end{array}$ & $\begin{array}{l}.016^{*} \\
(.009)\end{array}$ \\
\hline Nicaragua & $\begin{array}{l}-.056 \\
(.042)\end{array}$ & $\begin{array}{l}-.069^{* *} \\
(.027)\end{array}$ & $\begin{array}{l}.009 \\
(.007)\end{array}$ \\
\hline Costa Rica & $\begin{array}{l}-.090^{*} \\
(.052)\end{array}$ & $\begin{array}{l}-.110^{* *} \\
(.045)\end{array}$ & $\begin{array}{l}.016^{*} \\
(.009)\end{array}$ \\
\hline Panama & $\begin{array}{l}-.071 \\
(.046)\end{array}$ & $\begin{array}{l}-.101^{* *} \\
(.042)\end{array}$ & $\begin{array}{l}.013 \\
(.009)\end{array}$ \\
\hline Colombia & $\begin{array}{l}-.096^{*} \\
(.054)\end{array}$ & $\begin{array}{l}-.114 * * \\
(.045)\end{array}$ & $\begin{array}{l}.018^{*} \\
(.010)\end{array}$ \\
\hline Ecuador & $\begin{array}{l}-.094^{*} \\
(.051)\end{array}$ & $\begin{array}{l}-.112 * * \\
(.045)\end{array}$ & $\begin{array}{l}.017^{*} \\
(.009)\end{array}$ \\
\hline Bolivia & $\begin{array}{l}-.100^{* *} \\
(.051)\end{array}$ & $\begin{array}{l}-.125^{* *} \\
(.045)\end{array}$ & $\begin{array}{l}.019^{*} \\
(.009)\end{array}$ \\
\hline Peru & $\begin{array}{l}-.074 \\
(.054)\end{array}$ & $\begin{array}{l}-.104^{* *} \\
(.046)\end{array}$ & $\begin{array}{l}.014 \\
(.010)\end{array}$ \\
\hline Paraguay & $\begin{array}{l}-.068 \\
(.044)\end{array}$ & $\begin{array}{l}-.102 * * \\
(.044)\end{array}$ & $\begin{array}{l}.014 \\
(.009)\end{array}$ \\
\hline Chile & $\begin{array}{l}-.086^{*} \\
(.051)\end{array}$ & $\begin{array}{l}-.110^{* *} \\
(.047)\end{array}$ & $\begin{array}{l}.016^{*} \\
(.009)\end{array}$ \\
\hline Uruguay & $\begin{array}{l}-.116^{* *} \\
(.051)\end{array}$ & $\begin{array}{l}-.124^{* *} \\
(.045)\end{array}$ & $\begin{array}{l}.021^{* *} \\
(.010)\end{array}$ \\
\hline Argentina & $\begin{array}{l}-.088^{*} \\
(.049)\end{array}$ & $\begin{array}{l}-.111^{* *} \\
(.044)\end{array}$ & $\begin{array}{l}.016^{*} \\
(.009)\end{array}$ \\
\hline
\end{tabular}




$\begin{array}{llll}\text { Dominican Republic } & -.092 * & -.121^{* *} & .019^{*} \\ & (.055) & (.046) & (.010)\end{array}$

Standard errors in parentheses. $* * \mathrm{p}<0.05, * \mathrm{p}<0.1$ 
Table 1E. Number of Elite and Mass Supporters for Each Party from Surveys

\begin{tabular}{|c|c|c|c|c|c|}
\hline$\underline{\text { Party }}$ & $\underline{\text { Mass N }}$ & $\underline{\text { Elite N }}$ & Party & Mass N & $\underline{\text { Elite N }}$ \\
\hline PAN(MEX) & 248 & 53 & MPAIS(ECU) & 414 & 60 \\
\hline PRI(MEX) & 187 & 28 & MAS(BOL) & 878 & 55 \\
\hline PRD(MEX) & 236 & 32 & MNR(BOL) & 126 & 6 \\
\hline UNE(GTM) & 141 & 31 & PODEMOS(BOL) & 463 & 30 \\
\hline PP(GTM) & 54 & 17 & UN(BOL) & 130 & 6 \\
\hline ARENA(ES) & 182 & 28 & UPP(PER) & 117 & 35 \\
\hline FMLN(ES) & 263 & 29 & APRA(PER) & 218 & 27 \\
\hline $\mathrm{PCN}(\mathrm{ES})$ & 24 & 7 & UN(PER) & 24 & 14 \\
\hline $\mathrm{PL}(\mathrm{HON})$ & 374 & 43 & $\mathrm{AF}(\mathrm{PER})$ & 17 & 10 \\
\hline PN(HON) & 288 & 39 & ANR(PRY) & 477 & 23 \\
\hline PLC(NIC) & 147 & 18 & PLRA(PRY) & 238 & 16 \\
\hline FSLN(NIC) & 291 & 28 & MPQ(PRY) & 63 & 8 \\
\hline ALN(NIC) & 112 & 17 & UNACE(PRY) & 80 & 7 \\
\hline PUSC(CR) & 57 & 5 & PS(CHI) & 84 & 11 \\
\hline PLN(CR) & 306 & 25 & $\mathrm{PPD}(\mathrm{CHI})$ & 76 & 15 \\
\hline $\mathrm{PAC}(\mathrm{CR})$ & 132 & 17 & $\mathrm{PDC}(\mathrm{CHI})$ & 87 & 16 \\
\hline $\mathrm{ML}(\mathrm{CR})$ & 20 & 6 & $\mathrm{RN}(\mathrm{CHI})$ & 52 & 14 \\
\hline PS(PAN) & 39 & 7 & $\mathrm{UDI}(\mathrm{CHI})$ & 43 & 25 \\
\hline PRD(PAN) & 381 & 36 & EP/FA/NM(URY) & 392 & 47 \\
\hline $\mathrm{PA}(\mathrm{PAN})$ & 142 & 14 & PN(URY) & 163 & 29 \\
\hline PLC(COL) & 158 & 23 & PC(URY) & 51 & 9 \\
\hline $\operatorname{PDA}(\mathrm{COL})$ & 58 & 8 & FpV-PJ(ARG) & 185 & 53 \\
\hline $\mathrm{UN}(\mathrm{COL})$ & 122 & 19 & UCR(ARG) & 30 & 10 \\
\hline $\mathrm{CR}(\mathrm{COL})$ & 45 & 13 & PRD(DR) & 200 & 26 \\
\hline $\mathrm{PCC}(\mathrm{COL})$ & 45 & 15 & PLD(DR) & 603 & 56 \\
\hline
\end{tabular}


PRIAN(ECU) $26 \quad 6$

PSP(ECU) 22
PRSC(DR)

64

11

14 